\title{
THE GROWTH STRATEGIES ANALYSIS OF TEN WOODY PLANT SPECIES FOR EFFECTIVE REVEGETATION
}

\author{
RIDESTI RINDYASTUTI $^{1 *}$ and RETNO PENI SANCAYANINGSIH ${ }^{2}$ \\ ${ }^{1}$ Purwodadi Botanic Garden, Indonesian Institute of Sciences (LIPI), Pasuruan 67163, Indonesia \\ ${ }^{2}$ Laboratory of Ecology and Conservation, Department of Biology, Faculty of Biology, Universitas Gadjah Mada, \\ Yogyakarta 55281, Indonesia
}

Received 05 October 2016/Accepted 26 May 2017

\begin{abstract}
The growth strategies of plant species show the ecological role which is reflexed by their adaptation to environments and competitiveness. Those are essential in the study of the revegetation effectiveness. However, the growth strategies of plant species in various types of habitats have not yet been fully investigated. The objective of this study was to investigate the growth strategies of ten woody plant species which were naturalized from mangrove to lowland habitats in relation to their effectiveness for revegetation program. The seedling's growth was recorded during 4 months in Purwodadi Botanic Garden-LIPI from October 2014 to February 2015. Complete randomized design with plant species as a treatment using 3 replications was carried out to examine the plant's Relative Growth Rates (RGRs), their components, leaf nitrogen productivity and growth strategies.The study showed that RGRs of ten woody plants species varied across species. Based on the Pearson correlations, the plant's Net Assimilation Rates (NAR) and two ecological traits related to the root trait i.e. Nitrogen productivity and Specific Root Length (SRL) were strongly correlated with the RGRs. Heritiera littoralis, Diospyros discolor, Antidesma bunius, Scbleichera oleosa, Madbuca longifolia and Sysygium cumini have high RGRs but low Specific Leaf Area (SLA). B. asiatica has relatively low RGRs and SLA, while Dracontomelon dao have high RGRs and SLA. It showed that most of plant species studied, except $D$. dao achieve growth rates and competitiveness by developing strategies through forming fine roots to maximize its ecological function in nutrients uptake. Most of woody plant species are adaptive to dry lowland habitat and only $D$. dao potentially occupy the ecosystem. Furthermore, $D$. discolor and $S$. oleosa are highly recommended for revegetation in degraded tropical lowland areas.
\end{abstract}

Keywords: growth strategy, revegetation, RGR, root trait, woody plants

\section{INTRODUCTION}

Natural tropical forests are being destroyed at a rapid high rate, therefore the success of forest restoration continues to be a challenge. A restoration program could help reestablish a forest vegetation eventhough it is difficult to guarantee the successful recovery of its biodiversity (Elliott et al. 2013). Adequate knowledges on biology and ecology of plant species related to their adaptation to habitat conditions enhance their use for decission making in reforestation programs. Especially in the early stage, plant species commonly develop the strategies for using limited resource in their environments, adapting to stresses, competing

\footnotetext{
* Corresponding author: ride17@gmail.com
}

and associating with others species in order to preserve their existences in their distribution ranges. The growth strategies show the ecological role and contribution of plant species to an ecosystem and imply the direct result of evolutionary control by genetics (Kolb et al. 1990).

Growth strategies can be identified by analysing and comparing the growth rates, leaf and root traits since these two organs are essential in photosynthesis and nutrient uptake (Wright \& Westoby 2000). In a constant state and similar environment, plant species were reported to have interspecific differences in growth rate that indicate different results of ecological strategy of plant species (Lambers et al. 1998; Pugnaire \& Valladers 1999; Laughlin et al. 2010). In plants, the survival depends on growth rate that can not be acurately measured only by observing plant size. 
Thus, Relative Growth Rate (RGR) and its components were modeled to understand, compare and evaluate plant growth rate. RGR and its components such as NAR, SLA, LWR, and LAR (described in Table 2) tend to reveal more of the species traits than predict plant growth rate according to its habitat (Lambers et al. 1998; Pugnaire \& Valladers 1999).

Growth strategy is especially related to leaf and root trait which is reflected in SLA (leaf area per unit leaf dry mass) and in SRL (root length per unit root dry mass). SLA as an aboveground seemed to be easier to investigate than SRL. SRL has been suggested as the belowground analogue to SLA, and is considered as a morphological index of belowground species competitiveness (Cornelissen et al. 2003). Shipley (2002) reported that RGR of either woody and herbaceous plants have strong and positive correlation with NAR and have weak and negative correlation with SLA. According to Lambers et al. (1998) and Pugnaire and Valladers (1999), variation in RGR is determined mainly by SLA. The opposite result is partly caused by differences of irradiance level used in the experiments. In general, the contribution of RGR's component is influenced by irradiance level. At low irradiance, SLA becomes the most determinant factor of RGR, and NAR is the main determinant of RGR at high irradiance. Thus, plant species that possess different shade tolerances will show different responses in growth rate. In general, higher SLA is the main growth atribute which supports plant invasiveness in other types of habitat (Shipley 2002; Lambers et al. 1998; Pugnaire \& Valladers 1999), with an exception, the invasive woody species which are successful in mediterranean climates. This invasive woody species has a greater biomass allocation to roots than less-invasive species (Grotkopp \& Rejma'nek 2007).

The growth strategies of plant species adapted in tropic regions with various types of habitats and shade tolerances have not yet been fully investigated. On the other hand, plant interspecific variation in RGR and its components are important to study the species competitiveness for particular purposes such as land restoration, carbon sequestration, species invasiveness etc. Local plant species which possess high growth rates and are widely distributed in certain ecological range are highly recommended for restoration of degraded areas (Cairns 1995). Moreover, to grow the plant species from other types of habitats, the revegetation effectiveness and plant invasiveness should be managed by understanding plant ecological traits including growth rate, growth strategy related to SLA, carbon gain and physiological performance of exotic species compared to native plants (Pattinson et al. 1998; Grotkopp \& Rejma'nek 2007).

For this study, ten woody plant species were investigated because they originated from various types of habitats but were developed and planted for revegetation programs in tropical dry lowland areas. The effectiveness of these species for revegetation in dry lowland habitats should be investigated in terms of their growth strategies. This study could provide valuable insights on the variation among plant species and explain the ecological success and competitiveness of plants in certain habitats. Thus, the objectives of this study were to: 1) determine the interspecific variation in RGRs and its components among plant species in similar irradiance levels; 2) find out the ecological trait of ten woody plant species; and 3) identify the growth strategies of ten woody plant species and discuss their ecological trait related to their effectiveness for revegetation in dry low land habitat.

\section{MATERIALS AND METHODS}

\section{Plant Material}

The seedlings used in this study were from the plant collections of Purwodadi Botanic GardenLIPI. All species used in this study are C3 woody plant species (Rindyastuti \& Hapsari 2017). The Botanic Garden is located in Pasuruan, East Java, at $300 \mathrm{~m}$ asl. It has a semi-deciduous climate with monthly rainfall of $246.57 \mathrm{~mm}$ in the wet season and $38.2 \mathrm{~mm}$ in the dry season. The annual temperature ranges from 20.4 to $30.6^{\circ} \mathrm{C}$. Three seedlings were used for each treatment. Sixteenmonth old seedlings of ten local woody plant species used in this study are described in Table 1. 
Table 1 List of species, habitat, type of plant and shade tolerance of ten woody plant species observed in this study

\begin{tabular}{|c|c|c|c|}
\hline Species & Habitat & Type & Shade tolerance \\
\hline $\begin{array}{l}\text { Barringtonia asiatica (Lemmens et } \\
\text { al. 1995) }\end{array}$ & Mangrove, tropical coast & Evergreen woody & $\begin{array}{l}\text { Intermediate to } \\
\text { tolerant }\end{array}$ \\
\hline $\begin{array}{l}\text { Dracontomelon dao (Orwa et al. } \\
2009 \text { ) }\end{array}$ & $\begin{array}{l}\text { Monsoon forest (deciduous } \\
\text { and semi-deciduous) }\end{array}$ & $\begin{array}{l}\text { Semi-deciduous, } \\
\text { hardwood }\end{array}$ & Tolerant \\
\hline $\begin{array}{l}\text { Heritiera littoralis (Lemmens et al. } \\
\text { 1995) }\end{array}$ & Mangrove, tropical coast & Evergreen, hardwood & Tolerant \\
\hline $\begin{array}{l}\text { Diospyros discolor (Verheij \& } \\
\text { Coronel 1991; Lemmens et al. } \\
\text { 1995) }\end{array}$ & Dry lowland tropic & Evergreen hardwood & Tolerant \\
\hline $\begin{array}{l}\text { Calophyllum inophyllum (Sosef et al. } \\
\text { 1998; Orwa et al. 2009) }\end{array}$ & Coast-lowland tropic & Evergreen hardwood & Intolerant \\
\hline $\begin{array}{l}\text { Antidesma bunius (Sosef et al. } \\
\text { 1998; Orwa et al. 2009) }\end{array}$ & Highland tropic & Evergreen hardwood & Tolerant \\
\hline $\begin{array}{l}\text { Schleichera oleosa (Kundu \& } \\
\text { Schmidt 2011) }\end{array}$ & $\begin{array}{l}\text { Dry low-highland mix } \\
\text { deciduous forest }\end{array}$ & Deciduous hardwood & Tolerant \\
\hline $\begin{array}{l}\text { Sysygium cumini (Verheij \& } \\
\text { Coronel 1991; Orwa et al. 2009) }\end{array}$ & $\begin{array}{l}\text { Dry and moist tropical- } \\
\text { deciduous forest }\end{array}$ & Evergreen hardwood & Tolerant \\
\hline Madhuca longifolia (Sikarwar 2002) & Dry lowland tropics & $\begin{array}{l}\text { Evergreen-semievergreen, } \\
\text { hardwood }\end{array}$ & Tolerant \\
\hline $\begin{array}{l}\text { Adenanthera pavonina (Orwa et al. } \\
2009 \text { ) }\end{array}$ & Evergreen-deciduous forest & $\begin{array}{l}\text { Evergreen-deciduous, } \\
\text { woody }\end{array}$ & Tolerant \\
\hline
\end{tabular}

\section{Growth Conditions, Experimental Design and RGRs Measurement}

Seedlings of ten woody plant species were grown in horticultural pots under controlled and favourable conditions in a glasshouse located at Purwodadi Botanic Garden-LIPI, Pasuruan, East Java which has a temperature range of $26.2-30.8^{\circ} \mathrm{C}$ in the dry season and $28.7-34.6^{\circ} \mathrm{C}$ in the rainy season. Seedlings were watered every 2 days without fertilizer treatment. Seedlings were grown in a mixture of silica sand and compost with a ratio of 1:1. The experiment was caried out in complete randomized design using 3 replications with variation of species as its treatment. All seedlings were grown until 16 months then were transferred into bigger polybags with new plant media to record maximum resource uptake for their growth. Three seedlings for each replication at 16 months were harvested to obtain $\mathrm{W}_{1}$ and the seedlings were harvested 4 months later at 20 months to obtain $\mathrm{W}_{2}$. All seedlings were divided into three parts: leaf, stem and root. Plant materials were dried in an oven with temperature of $80^{\circ} \mathrm{C}$ to constant weight (Crescente \& Gratani 2013).

RGR was calculated using the following equation (Hoffmann \& Poorter 2002):

$$
\mathrm{RGR}=\left(\ln \mathrm{W}_{2}-\ln \mathrm{W}_{1}\right) /\left(\mathrm{t}_{2}-\mathrm{t}_{1}\right)
$$

Where:

$$
\begin{aligned}
& \ln =\text { natural logaritm } \\
& t_{1}=\text { time one } \\
& t_{2}=\text { time two } \\
& W_{1}=\text { dry weight of plant in time } 1 \\
& W_{2}=\text { dry weight of plant in time } 2
\end{aligned}
$$

The components of RGR observed in this study are listed and described in Table 2 . 
Table 2 List of abbreviations used in the text with definitions and units of measure

\begin{tabular}{llc}
\hline \multicolumn{1}{c}{ Abbreviations } & \multicolumn{1}{c}{ Definitions } & Units \\
\hline RGR & Relative Growth Rate & $\mathrm{gg}^{-1} \mathrm{day}^{-1}$ \\
LAR & Leaf Area Ratio (leaf area/plant dry mass) & $\mathrm{cm}^{2} \mathrm{~g}^{-1}$ \\
SLA & Specific Leaf Area (leaf area/foliagedry mass) & $\mathrm{cm}^{2} \mathrm{~g}^{-1}$ \\
LWR & Leaf Weight Ratio (foliage mass/plant dry mass) & $\mathrm{g} \mathrm{g}^{-1}$ \\
SWR & Stem Weight Ratio (stem mass/plant dry mass) & $\mathrm{g} \mathrm{g}^{-1}$ \\
RWR & Root Weight Ratio (root mass/plant dry mass) & $\mathrm{g} \mathrm{g}^{-1}$ \\
NAR & Net Assimilation Rate & $\mathrm{g} \mathrm{cm}^{-2} \mathrm{day}^{-1}$ \\
SRL & Specific Root Length (root length/root dry mass) & $\mathrm{cm}^{2} \mathrm{~g}^{-1}$ \\
LNP & Leaf Nitrogen Productivity (dry mass increase/unit leaf & $\mathrm{g} \mathrm{g-1}^{-1} \mathrm{day}^{-1}$ \\
\end{tabular}

\section{Leaf Area Measurement}

Leaf area were used as a component of parameters listed in Table 2. Leaf area was calculated by comparing the proportion of an area of $16 \mathrm{~cm}^{2}$ paper weight with the weight of the entire paper using comparison formula as follows:

$$
\mathrm{L} 2=\frac{\mathrm{L} 1 \times \mathrm{W} 2}{\mathrm{~W} 1}
$$

Where $\mathrm{L} 2=$ Leaf area

$\mathrm{L} 1=$ Area of sample paper

$\mathrm{W} 2$ = Paper weight

$\mathrm{W} 1=$ Weight of sample paper.

\section{Analysis of Nitrogen Productivity}

Leaves of the ten woody plants were oven dried at temperature of $80^{\circ} \mathrm{C}$ for 48 hours. Five $\mathrm{g}$ of leaf sample were grinded and analyzed using the Kjeldahl method (Bremmer 1965). The analyses were performed at the Soil Chemistry Laboratory, Faculty of Agriculture of Brawijaya University in Malang. Nitrogen productivity was reflected by the value of LNP (rate of dry mass increase/unit leaf nitrogen/unit time) which was calculated using the formula as follow:

Leaf Nitrogen Productivity $(\mathrm{LNP})=\frac{\text { dry mass increase }}{\text { leaf nitrogen } / \text { time }}$

\section{Seed Mass}

Seeds of the ten woody plant species were collected from the plant collection at Purwodadi Botanic Garden-LIPI, Pasuruan, East Java in
March 2016. Ten fresh seeds weight were measured for each woody plant species including the seed coat. The seed mass show plant strategies which were illustrated by L-H-S (Leaf trait, Height and Seed mass) scheme in several growthforms (Westoby 1998). This variable was used to determine plant strategies scheme of species studied, whether L-H-S scheme or others.

\section{Data Analyses}

The normality and randomity of data were tested using Kolmogorov-Smirnov and Run test. The normal data were analyzed using variance analysis (ANOVA) at confidence level of $95 \%$. Tukey's advance analysis was carried out for data grouping. The relationship among variables which have random data were analyzed using Pearson correlation test at confidence level of 95\% $\quad(\mathrm{P}<0.05)$, while relationships between unrandom data were analyzed using Spearman rank correlation test.

\section{RESULTS AND DISCUSSION}

\section{Interspecific Variation in RGR}

Based on the normality test, the mean of RGR and its components of the ten woody plants were normal. Based on the variance analyses, there was a significant difference in $\mathrm{RGR}(\mathrm{P}=0.014)$ and SLA, LAR, SWR, LWR and RWR with P values $0.0001,0.0001,0.0002,0.0002$, and 0.0001, 
respectively (significant if $\mathrm{P}<0.05$ ) among the ten woody plant species observed in this study. Mean of RGR ranged from $4 \times 10^{-3} \mathrm{~g} \mathrm{~g}^{-1} \mathrm{day}^{-1}$ for C. inophyllum and $10.7 \times 10^{-3} \mathrm{~g} \mathrm{~g}^{-1} \mathrm{day}^{-1}$ for S. cumini (Figure 1). Mean of initial SLA of the ten woody plant species ranged from 90.53 for $H$. littoralis to 298.56 for $D$. dao (Figure 2). During the seedling growth, the mean of SLA increased from 105.89 for $H$. littoralis to 321.58 for $A$. pavonina. The mean of initial LWR ranged from 0.094 for $A$. pavonina to 0.46 for $D$. discolor, while mean of LWR increased from 0.52 for $S$. cumini to 0.53 for $D$. discolor. The differences between species belonging to the lowest ratio and highest ratio of SLA and LWR show the differences of succulence level and leaf dry matter content among species (Wilson et al. 1999). The mean of initial SWR ranged from 0.14 for $D$. discolor to 0.49 for $S$. cumini. The mean of SWR increased from 0.29 for $D$. discolor to 0.61 for S. cumini in the end of observation. Less mass was stored in the stem of $D$. discolor than in its other parts. Mass allocations in the root was reflected by RWR (Figure 3). Mean of initial RWR ranged from 0.29 for $H$. littoralis to 0.54 for $A$. bunius. After 4 months of growth, the mean of RWR increased from 0.18 for $D$. discolor to 0.38 for B. asiatica. Other than RWR, root trait was also reflected by SRL (Figure 3). SRL ranged from 1.28 for B. asiatica to 7.2 for $D$. discolor in the initial growth and ranged from 1.52 to 10.86 at the end of the experiment.
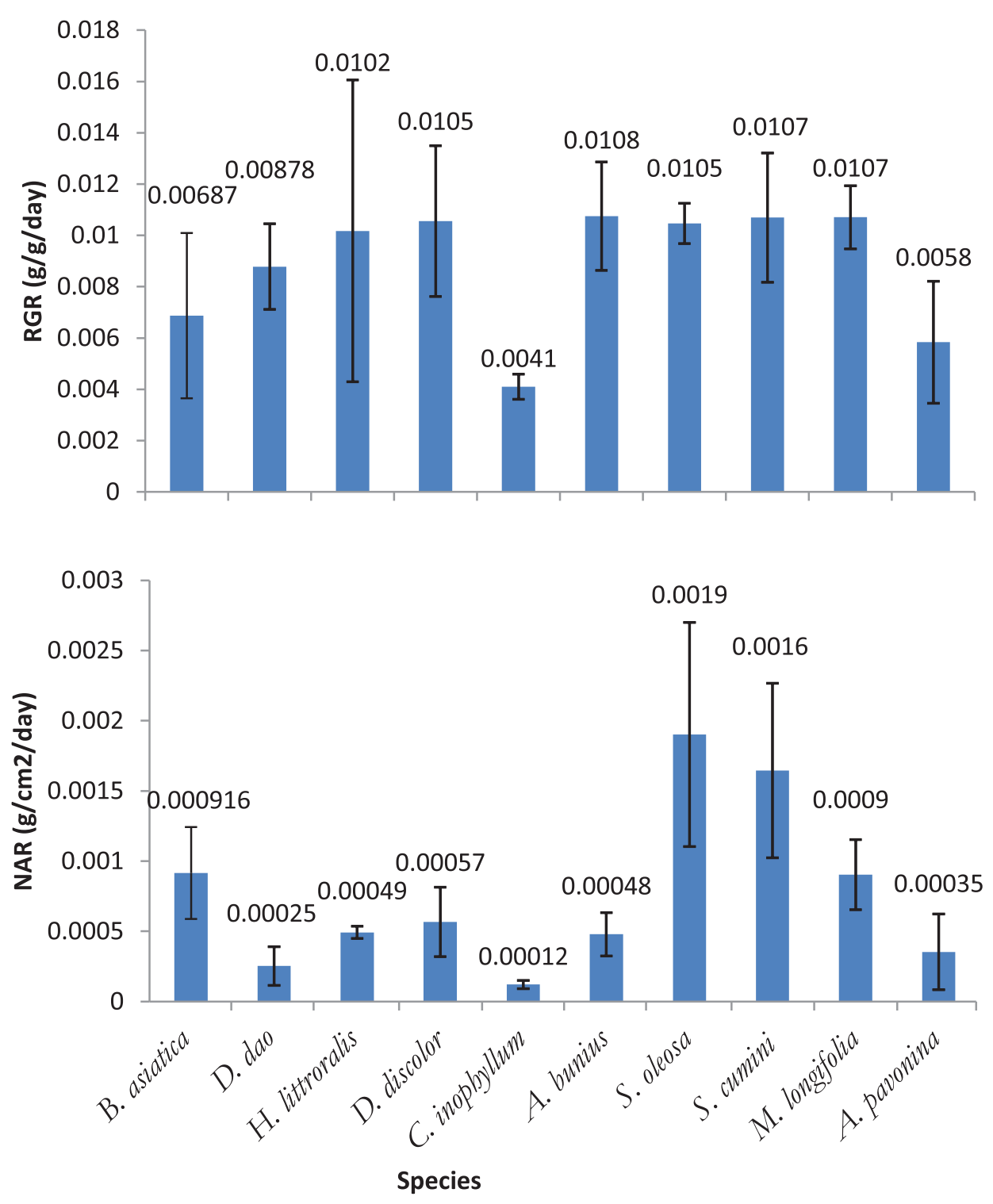

Figure 1 The mean of RGR and NAR of ten woody plant species

Note: RGRs and NAR were significantly different among species based on the variance analysis $(\mathrm{P}<0.05)$ 

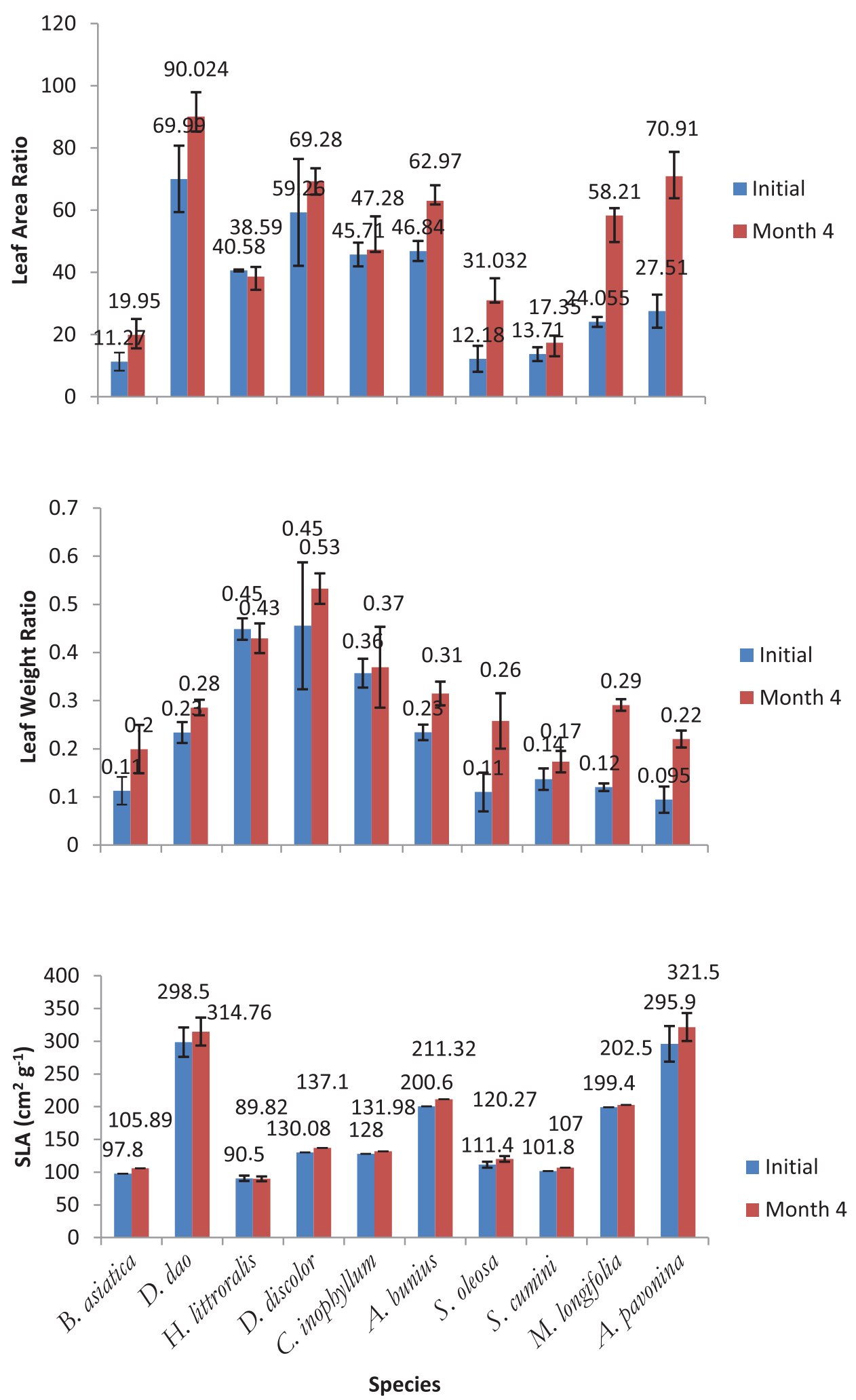

Figure 2 The comparison between mean components of RGR related to leaf trait (LAR, LWR and SLA) of ten woody plant species

(Note: The component of RGR related to leaf trait were significantly different among species based on the variance analysis $(\mathrm{P}<0.05))$ 

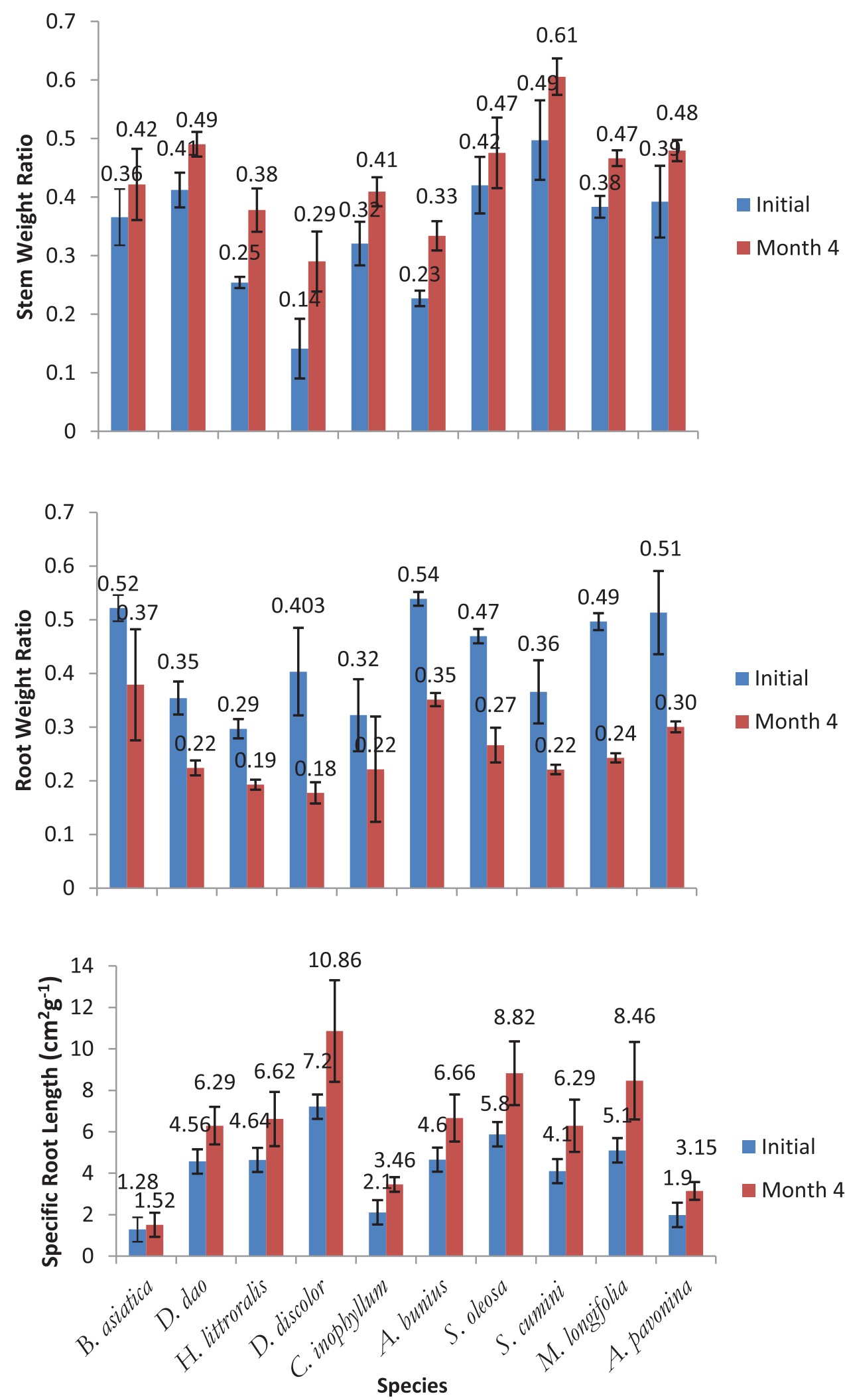

Figure 3 The mean of components of RGR related to stem and root traits represented by SWR, SRL and RWR of ten woody plant species

(Note: The components of RGR related to stem and root traits were significantly different among species based on the variance analysis $(\mathrm{P}<0.05)$ 


\section{Correlation among Components of RGR}

Correlation tests were performed to reveal the relationships between plant RGR and its components. The mean of RGRs of the ten woody plant species was strongly correlated with NAR (P value 0.0001) but not with other components (Figure 1, Table 3). The correlation explained the importance of NAR in determining RGR of woody plant species. Variations in other components did not explain the differences in RGR. NAR ranged from $1.2 \times 10^{-4} \mathrm{~g} \mathrm{~cm}^{-2} \mathrm{day}^{-1}$ for C. inophyllum to $1.9 \times 10^{-3} \mathrm{~g} \mathrm{~cm}^{-2}$ day ${ }^{-1}$ for S. oleosa. The NAR values of two species which are known as fast growing species i.e. $M$. longifolia and $A$. pavonina were more than a fifteen-fold difference with slow growing plants (Figure 1).

Interspecific variation in RGR and its components among species showed variation of ecological traits of plant species. The ecological traits can be shown by above ground trait supported by leaf trait or below ground trait supported by root traits which serves as a chosen strategy scheme of plant species in the habitat they occur (Laughlin et al. 2010; Grime 1979). In several previous studies, plant strategies were illustrated by L-H-S (Leaf trait, Height and Seed mass) scheme. Seed mass showed dependence with other growth component between different growth forms (Westoby 1998). For example, seed mass dependence of woody C3 was different from those of graminoids (Laughlin et al. 2010). In line with the previous study, the seed mass of ten woody plant species which included in woody C3 were not correlated with the height or leaf traits of plant species. Therefore, it indicated that plant strategy across species within similar growth form were not supported by seed mass but by leaf or root trait.

The plant size can not literally support the mass investment to plant structure because the value of RGR is mainly supported by dry matter content especially various lignin component (Laughlin et al. 2010). The larger plant could show lower RGR maybe because of the high level of water content in the plant body. The larger plant sometimes consist of abundant water than its dry matter content, for example B. asiatica and A. pavonina. Thus, the growth properties of plant species could not be observed only by the plant size thus, the study of growth rate and its components proves to be veryimportant.
The study result showed that the mean RGR of fast growing plants was more than two-fold difference from the slowest growing plant while NAR was a five-fold difference from the slowest growing plant. RGR of woody plants showed different pattern from those of non-woody species. According to Poorter and Remkes (1990), in C3 non-woody species, RGRs of the fastest growing species was three-fold more than those of the slowest growing species, while NAR of the fastest growing species was two-fold more than those of the slowest growing species. Fast growing species obtain an ecological advantage of a high RGR related to high competitiveness and rapid occupation (Poorter \& Remkes 1990). Therefore, the difference in NAR between the fast and slow growers seemed to be a trustworthy evidence of its contribution to differing RGR across plant species.

A strong correlation between RGRs and NAR of woody plant species showed how the high RGRs in fast growing species were achieved. Theoritically, RGR is the product of LAR and NAR. However, LAR did not seem to contribute to RGRs variation. While it is clear that two other growth components related to leaf formation (SLA and LWR) did not show its association with growth rate, this could be concluded that there was other more important growth plant behavior in carbon gain than to invest more mass to the leaf. NAR largely reflects the rate of photosynthetic carbon gain minus carbon released by respiration. Loveys et al. (2002) reported that correlation between RGR and NAR is more stable than the correlation between RGR and SLA. The effect of SLA to the variations in RGRs is more sensitive than NAR because it showed greater response in slight changes of radiance level. Moreover, SLA is an important plant functional trait as species which have higher SLA can obtain a more extensive foliage display that captures more light for biomass investment (Crescente \& Gratani 2013).

The mean of RGRs was correlated with SRL and LNP but not with SLA. Nitrogen productivity showed an important role in root trait of plant growth. When RGRs only correlated with root length and nitrogen productivity, this means that the woody plants in this study could achieve more mass through root trait than leaf trait (Wilson et al. 1999). It also explains how the 
fast growth of species studied can be achieved and how different RGRs across species are formed. The fast growing species have high RGRs and tend to allocate more mass to the leaves than to the roots. Therefore, the species studied have greater mass allocations to the roots and low RGR. Hunt and Cornelissen (1997) investigated that mean of RGRs of 59 temperate herbaceous species range from $0,1260 \mathrm{~g} \mathrm{~g}^{-1} \mathrm{day}^{-1}$ for Brachypodium pinnatum to $0,2741 \mathrm{gg}^{-1} \mathrm{day}^{-1}$ for Epilobium hirsutum. It indicated that all woody plants studied were slower growing plant compared to the most herbaceous species.

\section{Variation in Seed Mass}

Seed mass was one of physiological plant trait that being included into L-H-S (Leaf-HeightSeed) scheme proposed by Westoby (1998). L-H-S scheme is a plant ecological strategy which defined by Leaf trait, Heigh and Seed mass. Seed mass data of ten woody plant were not normal and not random with a $P$ value of normality test $0,01(\mathrm{P}>0.05)$, while the $P$ value of a run test was $P$ $0.0001(\mathrm{P}>0.05)$. Thus, seed mass of ten woody plant species were analysed and grouped descriptically. Seed mass of $B$. asiatica is the highest while those of $A$. bunius is the lowest (Figure 4). Seed mass can be grouped into big and small seed. Poorter and Rose (2005) clasified the weight of small seeds is $<0.1 \mathrm{~g}$ and large seed is $>0.1 \mathrm{~g}$. Therefore, the seed of all species studied were clasified as big seeds. Furthermore, there is no variation in seed mass across species studied that support interspesific variation in RGR.

\section{Nitrogen Productivity}

Leaf nitrogen was reflected in leaf $\mathrm{N}$ concentration and LNP (Leaf Nitrogen Productivity). Leaf $\mathrm{N}$ probably correlated with above or below-ground traits of plant species (Wright \& Westoby 2000). The mean of $\mathrm{N}$ concentration of ten woody plant ranges from $1.59 \%$ for $H$. littoralis to $3.03 \%$ for $A$. pavonina. Mean of LNP value ranges from $0.035 \mathrm{gg}^{-1} \mathrm{day}^{-1}$ for C. inophyllum to $0.24 \mathrm{~g} \mathrm{~g}^{-1} \mathrm{day}^{-1}$ for S. cumini. Based on the variance analysis, both total $\mathrm{N}$ and LNP were significantly different among species. It showed that $\mathrm{N}$ productivity vary amongs species and probably contribute to variation in RGRs. Based on the correlation test, LNP is correlated with RGRs and SLA $(\mathrm{P}<0.05)$ (Table 3). It showed that $\mathrm{N}$ productivity contribute to the variation in RGRs and leaf area. The mean of LNP of ten woody plant species are described in Figure 5.

The mean of RGR is strongly correlated with SRL but is not correlated with SLA while the mean of RGR is strongly correlated with LNP (Table 3). It indicated that the growth of ten woody plants is achieved through the growth of root length and high leaf nitrogen productivity. The strong correlation between root length and RGRs showed an important role of root function in plant growth. Two species which have high SRL during the growth are $D$. discolor and $S$. oleosa while the species which has the lowest SRL is B. asiatica. $D$. discolor and $S$. oleosa are considered native to dry lowland habitat while $B$. asiatica is a mangrove

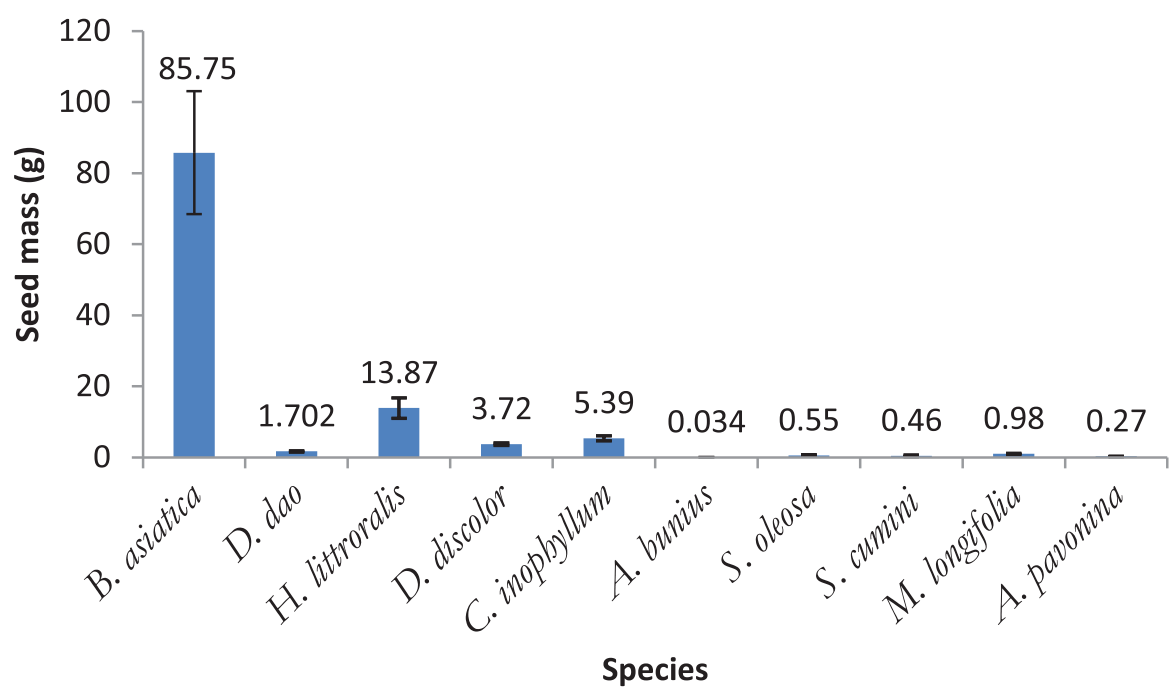

Figure 4 Seed mass of ten woody plants species

(Note: There was no variation in seed mass across species studied that support interspesific variation in RGR based on normality test $(\mathrm{P}>0.05)$ and run test $(\mathrm{P}>0.05))$ 


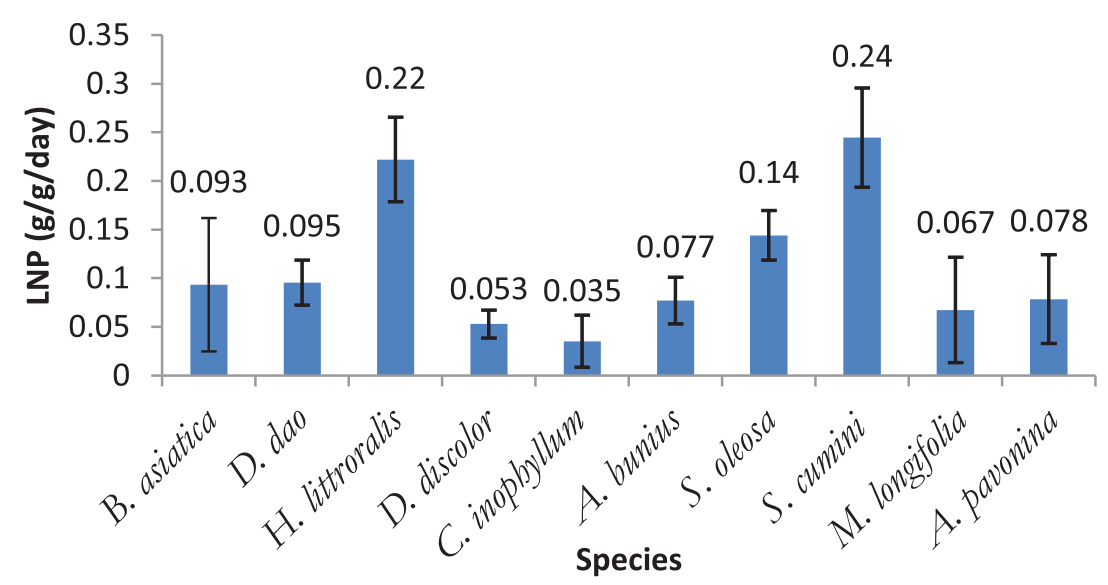

Figure 5 The mean of LNP of ten woody plants species

(Note: LNP were significantly different among species based on the variance analysis $(\mathrm{P}<0.05)$ )

Table 3 Pearson correlation coefficients between growth components $(\mathrm{P}<0.05)$

\begin{tabular}{lcc}
\hline \multicolumn{1}{c}{ Components } & P value & Correlation \\
\hline RGR and NAR & $\mathbf{0 . 0 0 0 1}$ & Strongly correlated \\
RGR and LAR & 0.64 & Not correlated \\
RGR and SLA & 0.2 & Not correlated \\
RGR and LWR & 0.57 & Not correlated \\
RGR and SWR & 0.88 & Not correlated \\
RGR and RWR & 0.48 & Not correlated \\
RGR and SRL & $\mathbf{0 . 0 0 0}$ & Strongly correlated \\
RGR and LNP & $\mathbf{0 . 0 0 0}$ & Strongly correlated \\
NAR and LNP & 0.056 & Not correlated \\
SLA and LNP & $\mathbf{0 . 0 0 0}$ & Strongly correlated \\
LWR and LNP & 0.2 & Not correlated \\
LAR and LNP & 0.1 & Not correlated \\
SWR and LNP & 0.267 & Not correlated \\
RWR and LNP & 0.302 & Not correlated \\
SRL and LNP & 0.58 & Not correlated \\
Seed mass and RGR & 0.87 & Not correlated \\
Seed mass and LWR & 0.67 & Not correlated \\
Seed mass and SWR & 0.97 & Not correlated \\
Seed mass and RWR & 0.47 & Not correlated \\
Seed mass and SRL & 0.45 & Not correlated \\
Seed mass and height & 0.28 & Not correlated \\
\hline
\end{tabular}

species that is likely to poorly survive in dry area. SLA is strongly correlated with LNP. Among the studied species, the highest SLA was found in $D$. dao and $A$. pavonina. These two species are known as semi-deciduous species (Table 1 ).

\section{Leaf or Root Trait}

RGRs of ten woody species were correlated with SRL but were not correlated with SLA, while mean of RGRs was correlated with LNP. The strong correlation between RGRs with root length and leaf nitrogen productivity explained that most of woody plant in this study could achieve more mass through root trait than leaf trait (Wilson et al. 1999). Moreover, related to the growth properties of plant species, most species allocated greater mass to the leaves than to roots, but slow growing species with low RGR commonly partitioned greater proportion of new biomass to the roots rather than to the leaves (Wright \& Westoby 2000). Therefore, most of 
species studied were clasified as slow growing species.

The species which develop the root traits tend to be clasified as slow growing plant. Based on the correlation among the RGR components, most of species studied were clasified as slow growing species which develop root trait in achieving mass for plant growth. Among these species, $D$. discolor and $S$. oleosa are good examples for this growth strategies. In these two species, the highest RGR and SRL were found, yet the SLA was relatively low.

$M$. longifolia and $A$. pavonina were known as fast growing woody plants. The RGR of $M$. longifolia was as high as those of other species while RGR of A. pavonina was low. A. pavonina has low RGR although it has the highest SLA while $M$. longifolia has a high RGR yet low SLA. Because species which are confirmed as a fast growing species should show high RGR and SLA, it is difficult to confirm that these two wellknown species are fast growing species. Moreover, both species had among the largest increase in LAR through time and the largest decrease in RWR. A. pavonina which has high SLA and high increase of LAR yet large decrease of RWR may exhibit different ecological strategies from other species studied. This species tend to develop leave trait than root trait.

In addition, in most of species studied, the increase of SRL and the decrease of RWR were found. The formation of long root which is combined with the low roots dry mass could mean that plants in this study tended to form more fine roots to reach a wider range of water and nutrients. It showed a pattern of growth to form long root inspite of large foliage display to capture more light. The fine roots could clearly explain the growth strategies through root trait of the ten species studied.

\section{Implication to Land Revegetation}

Because of the massive biodiversity loss in recent years, forest restoration should be established in the framework of conservation to restore forest biodiversity and its ecological functions. Cairns (1995) recommended native and local plant species to restore destroyed forest ecosystem. Native and local species tend to have relatively slow growth and limited leaf expansion. On the other hand, fast growing plants which have wide ecological range distribution are highly recommended to restore degraded areas because of their ability for rapid establishment and coverage. However, non-native fast growing plants have greater potential to invade areas because of their ecological advantage of having a high RGR for high survival, competitiveness and rapid occupation (Poorter \& Remkes, 1990; Haggar et al. 1998; Mahari \& Giday 2014).

Invaders are more likely to have higher RGRs, leaf area and tissue construction costs (Daehler 2003), with an exception of woody plants thriving well in mediterranean climates which have greater allocation to roots than less invasive species (Grotkopp \& Rejma'nek 2007). Further, higher SLA is strongly correlated to plant invasiveness (Lambers et al. 1998; Pugnaire \& Valladers 1999). Most of the woody plant species in this study obtained their RGRs by developing root trait which showed that these species are less invasive and recommended for regenerating forest vegetation in dry lowland areas.

Dry tropical climate is a condition with relatively high temperatures and low water availability compared to other tropical climates such as rainforest areas. In dry tropical areas, plants are adapted to have mechanisms to reduce water loss through low transpiration and reach the water balance by absorbing water from the soil. Root traits is a competitive advantage with respect to the dry climate with high air temperature and low water availability. Adaptive roots have more fibers which can reach water in wider and deeper soil. Because root function was correlated with the mean of RGRs, several species which have high RGRs yet relativelly low SLA are considered to be well adapted to dry climate such as $H$. littoralis, $D$. discolor, A. bunius, $S$. oleosa, M. longifolia, and S. cumini. Several species are known as native plants to dry lowland habitat. Native species are preferred to be reintroduced in degraded areas to fix damaged soil by restoring soil fertility and enhancing microbe population which provides sufficient nutrients for plants (Álvarez-Sánchez et al. 2009). Based on this study, native species are considered to have high RGRs which supported by root trait thus they are highly recommended for restoration programs in degraded areas. Of the species studied, $D$. discolor and $S$. Oleosa, which are native to dry lowland areas yet have high RGR and developed fine 
roots, are highly recommended for revegetation in dry lowland habitat.

$B$. asiatica is a native species to mangrove habitat which has relatively low RGR and SLA, while $D$. dao which is adapted to monsoon forest has high RGR and SLA. This indicates that B. asiatica exhibits relatively low competitiveness and occupation potential compared to other species. For being introduced to other types of habitat, non-native species are better of having low competition so that the species do not occupy the plant community in new habitat (Bazzaz 1979). Hence, B. asiatica can be more recommended for planting program in dry lowland habitat than $D$. dao. Based on the high RGR and SLA, D. dao expands larger foliage to capture more sunlight. Therefore, this species has the potential to occupy the ecosystem. Other species which have high SLA but low RGR, i.e. A. pavonina, may develop growth strategies through leaf trait but do not potentially invade the ecosystem. For further study, it is suggested to investigate whether $D$. dao release allelopathy, provide ground water and co-occur with other species and growthform to reveal the ecological suitability to new habitat in order to examine the effect of plant growth to soil and plant community. The ecosystem services of a species relating to root trait should be highlighted to maximize the advantage of restoration such as for hydrological services in degraded landscapes (Bruijnzeel 2004; Hall et al. 2011).

\section{CONCLUSIONS}

There are variations in RGRs across the ten woody plants species as determined by NAR, nitrogen productivity and root trait. To achieve the growth rates and competitiveness, the woody plant species studied tend to develop strategies through forming fine roots to maximize its ecological function in nutrient uptake except $D$. dao. Most of the woody plant species are adaptive to dry lowland habitat and only $D$. dao has the potential to occupy the ecosystem. D. discolor and S. oleosa are highly reccomended for revegetation programs in degraded tropical lowland areas.

\section{ACKNOWLEDGEMENTS}

The authors would like to thank Kemenristek Dikti Scholarship which support the whole project of ecophysiological study of woody plants and Dr Titut Yulistyarini as co-promotor. We like to thank Mr. Riyadi and Mr. Roif Marsono for their technical contributions during experiment in Purwodadi Botanic Garden-LIPI. We also like to thank Ms. Samantha Tesoriero for writing consultation.

\section{REFERENCES}

Álvarez-Sánchez J, Sánchez-Gallen I, Guadarrama P. 2009. Analyses of ecophysiological traits of tropical rain forest seedlings under arbuscular mycorrhization: Implications in ecological restoration. In: Varma A, Kharkwal AC, editors. Symbiotic Fungi: Principles and Practice. Berlin (DE): Springer-Verlag Berlin Heidelberg. p. 293-305.

Bazzaz FA. 1979. The physiological ecology of plant succession. Annu Rev Ecol Syst 10:351-71.

Bremmer JM. 1965. Determination of nitrogen in soil by kjeldahl method. J Agric Sci 55:11-33.

Bruijnzeel LA. 2004. Hydrological functions of tropical trees: Not seeing the soil for the trees. Agric Ecosyst Environ 104:185-228.

Cairns J. 1995. Rehabilitating damaged ecosystem, $2^{\text {nd }}$ edition. Florida (US): CRC Press. p. 110-40.

Cornelissen JHC, Lavorel S, Garnier E, Diaz S, Buchmann N, Gurvich DE, ... Pooter H. 2003. A handbook of protocols for standardised and easy measurement of plant functional traits worldwide. Aust J Bot $51: 335-80$

Crescente MF, Gratani L. 2013. Differences in morphological, physiological and growth traits between two endemic subspecies of Brassica rupestris Raf.: Implications for their conservation. Am J Plant Sci 4(6A):42-50.

Daehler CC. 2003. Performance comparison of cooccuring native and alien invasive plants: Implication for conservation and restoration. Annu Rev Ecol Evol Syst 34:183-211.

Elliott SD, Blakesley D, Hardwick K. 2013. Restoring tropical forests: A practical guide. Kew (UK): Royal Botanic Gardens, Kew. 344 p.

Grime JP. 1979. Plant strategies and vegetation processes. Chichester (UK): John Wiley \& Sons, Ltd.

Grotkopp E, Rejma'nek M. 2007. High seedling relative growth rate and specific leaf area are traits of 
invasive species: Phylogenetically independent contrasts of woody angiosperms. Am J Bot 94(4):526-32.

Haggar JP, Briscoe CB, Butterfield RP. 1998. Native species: A resource for the diversification of forestry production in the lowland humid tropics. For Ecol Manag 106:195-203.

Hall JS, Ashton MS, Garen EJ, Jose S. 2011. The ecology and ecosystem service of native trees: Implication for reforestration and land restoration in Mesoamerica. For Ecol Manag 261:1553-7.

Hoffmann WA, Poorter H. 2002. Avoiding bias in calculations of relative growth rate. Ann Bot 90(1):37-42.

Hunt R, Cornelissen JHC. 1997. Components of relative growth rate and their interrelations in 59 temperate plant species. New Phytol 135:395-417.

Kolb TE, Steiner KC, McKormick LH, Bowersox TW. 1990. Growth response of Northerm red-oak and yellow-poplar seedlings to light in relation to ecological strategy. For Ecol Manage 36:65-78.

Kundu M, Schmidt LH [internet]. 2011. Schleichera oleosa (Lou.) Oken. seed leaftlet. Copenhagen, DK: University of Copenhagen; [cited 2016 Apr 13]. Available from: http://curis.ku.dk/ws/files/ 34317454/Schleichera_oleosa.pdf

Lambers H, Chapin FS, Pons TL. 1998. Plant physiological ecology. New York (US): Spinger-Verlag. p. 299-322

Laughlin DC, Leppert JJ, Moore MM, Sieg CH. 2010. A multi-trait test of the leaf-height-seed plant strategy scheme with 133 species from a pine forest flora. Funct Ecol 24:493-501.

Lemmens RHMJ, Soerianegara I, Wong WC. 1995. Plant resources of South-east Asia No. 5(2): Timber trees: Minor commercial timbers. Leiden (NL): Backhuys Publishers.

Loveys BR, Scheurwater I, Pons TL, Fitter AH, Atkin OK. 2002. Growth temperature influences the underlying components of relative growth rate: an investigation using inherently fast- and slowgrowing plant species. Plant Cell Environ 25(8): 975-88.

Mahari A, Giday K. 2014. Initial growth responses of five multipurpose tree species under moisture stressed environment, Northern Ethiopia: Implication for rehabilitation in degraded areas in the drylands. MRJASSS 2(8):104-10.
Orwa C, Mutua A, Kindt R, Jamnadass R, Anthony S. 2009. Agroforestree database: $A$ tree reference and selection guide, version 4.0. Available from: http://www.worldagroforestry.org/sites/treedbs/ treedatabases.asp

Pattinson RR, Goldstein G, Ares A. 1998. Growth, biomass allocation and photosynthesis of invasive and native Hawaiian rainforest species. Oecologia 117:449-59.

Poorter H, Remkes C. 1990. Leaf area ratio and net assimilation rate of 24 wild species differing in relative growth rate. Oecologia 83:553-9.

Poorter L, Rose SA. 2005. Light-dependent changes in the relationship between seed mass and seedling traits: A meta-analysis for rain forest tree species. Oecologia 142:378-87.

Pugnaire IF, Valladares F. 1999. Handbook of functional plant ecology. New York (US): Marcel Dekker, Inc. p. 81-121.

Rindyastuti R, Hapsari L. 2017. Adaptasi ekofisiologi terhadap iklim tropis kering: Studi anatomi daun sepuluh tumbuhan berkayu. J Biologi Indones 13(1):1-15.

Shipley B. 2002. Trade-offs between net assimilation rate and specific leaf area and determining Relative Growth Rate: Relationship with daily irradiance. Funct Ecol 16:682-98.

Sikarwar RLS. 2002. Mahua [Madhuca longifolia (Koen) MacBride]-A paradise tree for the tribals of Madhya Pradesh. Indian J Traditional Knowledge 1(1):87-92.

Sosef MSM, Hong LT, Prawirohatmodjo S. 1998. Plant resources of South-East Asia no. 5(3): Timber trees: Less-known timbers. Leiden (NL): Backhuys Publisher.

Verheij EWM, Coronel RE. 1991. Plant resources of SouthEast Asia No. 2: Edible fruit and nuts. Wageningen (NL): Pudoc.

Wilson PJ, Thompson K, Hodgson JG. 1999. Specific leaf area and leaf dry matter content as alternative predictors of plant strategies. New Phytol 143:15562.

Wright IJ, Westoby M. 2000. Cross-species relationships between seedling Relative Growth Rate, nitrogen productivity and root vs leaf function in 28 Australian woody species. Funct Ecol 14(1):97-107.

Westoby M. 1998. A leaf-height-seed (LHS) plant ecology strategy scheme. Plant Soil 199:213-27. 